Journal of Speech Sciences 4(2) 59-72.2014

Available at: www.journalofspeechsciences.org

\title{
A comparative prosodic study of questions in French in contact with Occitan and Catalan
}

Philippe Boula de Mareüil, Albert Rilliard, Fanny Ivent, Varvara Kozhevina LIMSI-CNRS, Orsay, França

\begin{abstract}
In the south of France, the French language has developed in contact with Occitan in Provence and Languedoc, in contact with Catalan in Roussillon. This study reports on a first analysis of data collected in these regions, during a field survey carried out among speakers of Occitan and Catalan, in addition to French. In particular, we compared the prosody of yes/no questions ending in a word stressed on the penultimate syllable (e.g caserna 'barracks' in Occitan or Catalan, caserne with a pronounced final schwa in southern French). On the last two syllables of questions, it turns out that the rising-rising pitch pattern is the most common and, according to a perception experiment using prosody modification/resynthesis, that it is preferred to a falling-rising pattern by southern French listeners (without significant differences between Provence and Languedoc). A falling-rising pattern was also observed in Roussillon, possibly resulting from a prosodic transfer from Catalan to French. It was not associated with that region by southern French listeners who took part in a second perceptual experiment. Yet, the intonation patterns found may have different functions: the rising-rising pattern, especially, is most often interpreted as a confirmation query.
\end{abstract}

Key words: prosody in contact; southern accents in French; endangered languages.

\section{Introduction}

Interrogation is a key aspect of prosody since, in many languages, intonation distinguishes questions from statements. In French, for example, the interrogative nature of an utterance is commonly marked only by a pitch rise on the last word (Martinet, 1970: 25-26). In this sense, prosody at the utterance-level plays a role comparable to the lexical- level distinctive function of tones in tone languages, in which pitch serves to contrast words of different meanings. In the spoken French sentences "il vient" "he is coming' and "il vient?" 'is he coming?', a pitch rise in the latter case has the same value as a syntactic marker (the verb and subject pronoun inversion) or a lexical marker (the introducer est-ce que 'is it that'). In spontaneous French conversations where questions indicated by intonation alone are the most frequent (Grundstrom \& Léon, 1973), it is the same as in other Romance languages like Italian and Occitan. There is thus a long tradition of research on the specific characteristics of interrogative intonation (Delattre, 1966; Fónagy, 2003; Savino, 2012), even though Occitan is obviously less studied.

In French, polar questions (requiring yes/no-type answers), the melodic rise is usually associated with the last stressed syllable of the utterance (Di Cristo, 1998). The high tone may be located earlier in the question, if the utterance is introduced by est-ce que, if one asks for confirmation rather than information and, regardless of this bias, in some French varieties such as French spoken in Corsica (Boula de Mareuil et al., 2015). Yet, in

JoSS 4 (2) $59-72$ 
"standard" (Parisian) French, the last stressed syllable of the utterance almost always coincides with the final syllable. Stress falls on the last syllable of word phrases or on the syllable preceding a phrase-final schwa; now this final schwa is usually elided in non- southern French (Di Cristo, 1998). What is the prosodic pattern of this final schwa in southern French varieties where the schwa is more often pronounced? The present study first aims at answering this question.

In a pilot study on the intonation of French in contact with Occitan, SichelBazin et al. (2012) observed rising movements or (sometimes) falling movements on the final schwa of yes/no questions, possibly with different epistemic functions: request for information in the first case, confirmation query in the second case. Does this hold for Languedoc as well as for Provence? What about French in contact with Catalan spoken in Roussillon? Catalan interrogative sentences show considerable variation in intonation, depending on their structure (Subject Verb Object or que Verb Object Subject) and dialect (Prieto, 2001; Vanrell et al., 2013). However, the fallingrising pattern seems to prevail in questions ending in a paroxytone - with a pitch fall on the penultimate, stressed, syllable and a rise on the final syllable (Celdrán Martínez et al, 2005).

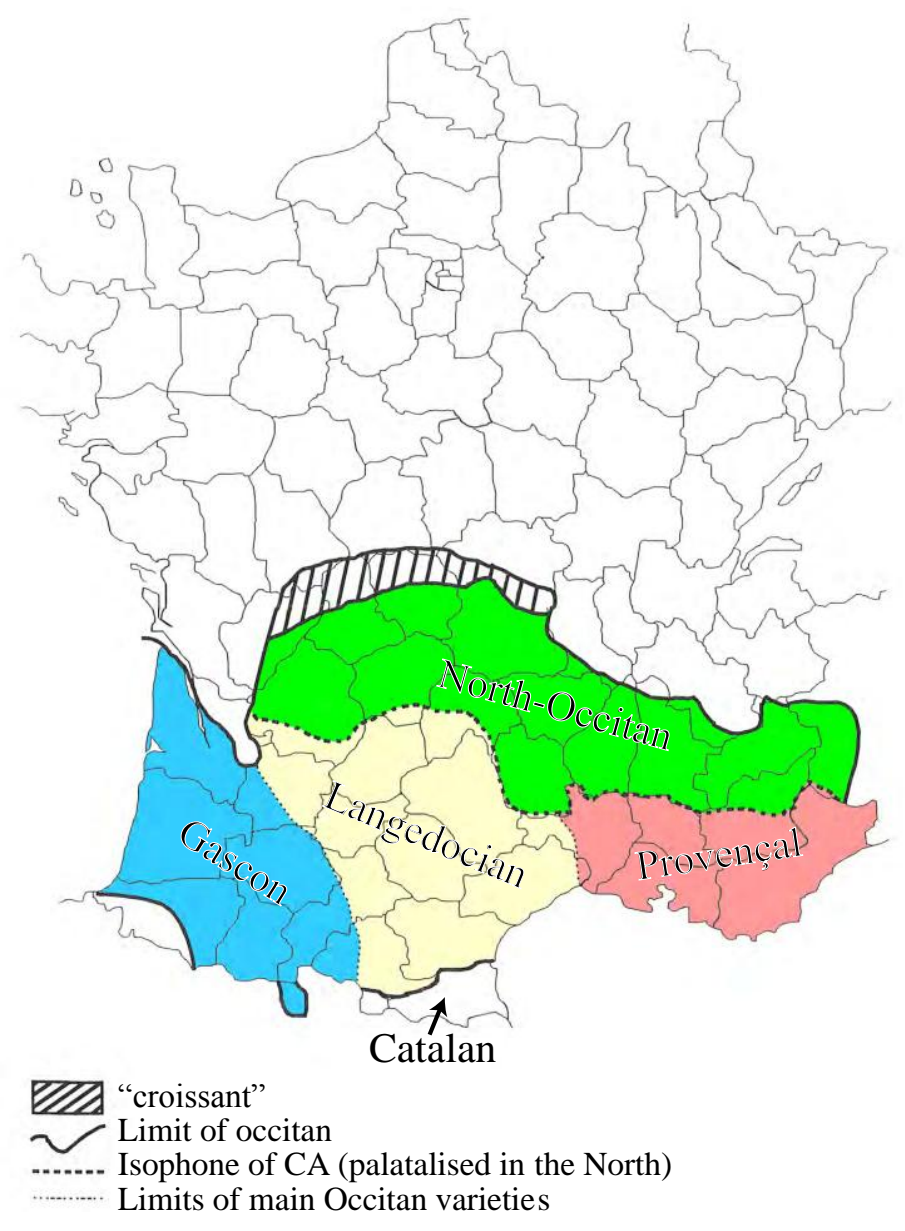

Fig. 1: map of Catalan and Occitan varieties in France, based on the description by Tuaillon (1996, reproduced with kind permission of the editor.

This paper reports on the first analysis of recordings collected during fieldwork carried out in Provence, Languedoc and Roussillon, with 28 Occitan-French or 
Catalan-French bilinguals (see Figure 1). The following sections present the background and hypotheses (Section 2), the survey and the corpus (Section 3). Various intonation patterns were observed for yes/no questions, in southern French as in Occitan and Catalan. These observations (provided in Section 4) led us to design two perceptual experiments, using prosody modification. A first experiment (Section 5) sought to determine whether, based on French questions spoken by Provençals and Languedocians, listeners from Provence and Languedoc were more accustomed to a particular pitch pattern. A second experiment (Section 6) extended the test to both speakers and listeners from Roussillon, with a twofold task: identify the speakers' regional background and the question type (with a bias towards a yestype answer, a no-type answer or no bias).

\section{Context and hypotheses}

Occitan and Catalan are two related Romance languages, mainly spoken in the south of France and Catalonia, respectively. While Occitan is today an endangered language (Meisenburg, 2011), Catalan is booming beyond the Pyrenees, in Spain. Once in decline, Catalan is in this respect a rare case of language shift reversal (Fishman, 1991; Boyer, 2004). The historical territory of the Catalan countries extends to the French Roussillon sub-region, where the linguistic situation is however quite different: only the language of the Republic has an official status recognized by the French Constitution. Even though schooling in Catalan has been allowed since the 1951 Deixonne Act (as elsewhere, the Occitan language), the population now mostly speaks French, the language of daily use in public space in France, Catalan now has 132,000 adult speakers, on a traditionally Catalan-speaking territory of about 400,000 people, and Occitan has 526,000 speakers, on a larger traditionally Occitan-speaking territory of about 15 million people (Héran et al. 2002). We here consider Provençal as an Occitan dialect without ignoring that it is sometimes regarded as a distinct language (Blanchet, 2004). Similarly, whereas Coquillon (2005) notes prosodic differences between French varieties spoken in Provence and Languedoc, other studies rather put forward similarities (Woehrling \& Boula de Mareüil, 2006; Sichel-Bazin et al., 2015).

In this article, we will build on the autosegmental-metrical model (Pierrehumbert, 1981), recently adapted to Occitan and French in contact with Occitan (Hualde, 2003; Sichel- Bazin et al, 2012, 2015). Even if a pitch rise on the last stressed syllable of the utterance continuing until the end is the most common configuration in Occitan and French in contact with Occitan (Sichel-Bazin et al., 2012, 2015), other patterns exist (Hualde, 2003).

Let us first examine Occitan and French in contact with Occitan, according to Sichel- Bazin et al. (2012, 2015). The rising-rising contour (henceforth denoted $\mathrm{H}^{*} \mathrm{H} \%$ ) is mainly used when the speaker requests information from his/her interlocutor, without assumptions about the answer. In confirmation requests, where the expected answer is yes, a rising-falling movement (henceforth denoted $\mathrm{H}^{*} \mathrm{~L} \%$, rising on the last stressed syllable of the utterance, then falling) is the preferred option. In incredulous questions, where the expected response is no, the shade of doubt is indicated by a low tone on the last stressed syllable of the utterance, followed by a pitch rise (henceforth denoted $\mathrm{L}^{*} \mathrm{H} \%$ ). 
In Roussillon Catalan as in other Catalan dialects, according to Sichel-Bazin and Roseano (2013), the $\mathrm{L}^{*} \mathrm{H} \%$ pattern is the most characteristic of information requests. In confirmation queries, according to these authors, the $\mathrm{H}^{*} \mathrm{H} \%$ rise is more usual. As far as incredulous questions are concerned, exhibiting a $\mathrm{L}^{*} \mathrm{H} \%$ pattern, they are usually distinguished from mere information requests by a wider pitch range. These different patterns are summarized in Figure 2. We are not aware of prosodic studies on Roussillon French, even if a field survey was recently carried out within the framework of the Phonology of Contemporary French project (Durand et al., 2009). Nevertheless, an interference between the dialectal substrate and regional French would suggest that this functional specificity should be reflected in Roussillon French, thus distinguishing it from the French variety spoken in the Occitan area.

\begin{tabular}{|c|c|c|c|}
\hline $\begin{array}{c}\text { Function in } \\
\text { Occitan }\end{array}$ & $\begin{array}{c}\text { request for } \\
\text { information }\end{array}$ & $\begin{array}{c}\text { confirmation } \\
\text { query }\end{array}$ & $\begin{array}{c}\text { incredulous } \\
\text { question }\end{array}$ \\
\hline Pattern shape & & $\mathrm{H}^{*} \mathrm{H}^{\circ} \%$ & $\mathrm{H}^{*} \mathrm{~L} \%$ \\
\hline $\begin{array}{c}\text { Function in } \\
\text { Catalan }\end{array}$ & $\begin{array}{c}\text { confirmation } \\
\text { query }\end{array}$ & - & $\begin{array}{c}\text { request for } \\
\text { information }\end{array}$ \\
\cline { 2 - 4 }
\end{tabular}

Fig. 2: Schematic representation of intonational contours of question endings in Occitan and Catalan, with their functional interpretation by Sichel-Bazin et al. $(2012,2015)$.

Note that questions may begin with es que in Occitan, és que in Roussillon Catalan, which parallel the French est-ce que. This solution, however, resulting from language contact, seems to be rarer than in French (Sichel-Bazin et al., 2012, 2015). Also, in Roussillon Catalan, questions in que Verb Object Subject (VOS) have been documented (Sichel-Bazin \& Roseano, 2013). We will return to this.

\section{Survey and corpus}

Recordings were made in Occitan and French around Avignon (Provence) and Montpellier (Languedoc), in Catalan and French around Perpignan (Roussillon). Occitan speakers (5 in Provence, 9 in Languedoc) and Catalan speakers belonged to various socioprofessional categories. In total, 14 Occitan speakers (8 males and 6 females, aged 49 on average) and 14 Catalan speakers (5 males and 9 females, aged 52 on average) were recorded - with a high-quality microphone, at $44.1 \mathrm{kHz}$ :

- reading sentences with tightly controlled structures, repeated in interrogative and assertive modalities (that are designed to be relatively transparent in various Romance languages);

- reading a text in French, before translating it into Occitan/Catalan;

- during semi-directed interviews in both French and Occitan/Catalan.

The data were collected alternating between the spoken regional language and French at each change of task. The controlled sentences were presented in random order. Speakers were asked to read each series (in Occitan/Catalan or French, with at least one repetition): each sentence was elicited first in the interrogative modality and followed immediately by the same sentence in the assertive modality. 
These controlled sentences met the requirements of the AMPER (Multimedia Prosodic Atlas of the Romance Area) project (Contini et al., 2002), as one of the aims of the investigation was to enrich this dialectological atlas and to allow comparisons with other Romance languages including Corsican (Bula Mareuil et al., 2013, 2015).

In compliance with the AMPER protocol, the designed sentences, of a dozen syllables on average, had dissyllabic verbs, trisyllabic nouns and expansions with various accentual patterns. Examples of such sentences are displayed in Table 1, using the "classical" Occitan written form. In practice, these sentences were presented to the subjects in such a way to be suited to dialectal particularities, following the Mistralian norm preferred by the Provençal speakers, including trovo, for instance, instead of tròba 'finds'.

\begin{tabular}{|l|c|c|}
\hline French & La touriste malade trouve la caserne ? & Le podestat trouve la cavité profonde ? \\
Occitan & La torista malauta tròba la caserna? & Lo podestat tròba la cavitat prefonda? \\
Catalan & La turista malalta troba la caserna? & El podestat troba la cavitat profunda? \\
English & Does the sick tourist find the barracks? & Does the Podestà find the deep cavity? \\
\hline
\end{tabular}

Table 1: examples of transparent sentences in French, Occitan and Catalan (with the English translations).

In French, stress always falls on the last syllable of word phrases — or on the syllable preceding a phrase-final schwa (e.g. Di Cristo 1998). In Catalan, by contrast, words can be oxytone, paroxytone or proparoxytone (i.e. stressed on the last, penultimate or antepenultimate syllable, respectively). Occitan, except in some peripheral varieties, lost its proparoxytones: stress is either on the last or next to last syllable of content words. Roussillon Catalan experienced the same trend; but proparoxytone words can still be heard in Perpignan, heavily exposed through education and the media to central Catalan spoken in Barcelona especially, which serves as a standard. We therefore included words like comica 'comic' in the Roussillon survey, something we have not done in Provence or Languedoc. In these latter cases, the number of different sentences was 34 in Occitan (and as many in southern French), as compared to 60 in Roussillon Catalan and French. Since the number of controlled sentences was lower in Occitan, each set of questions and statements was repeated three times, following the guidelines of the AMPER project.

In addition to alternating questions and statements where word order Subject Verb Object (SVO) remained unchanged, we asked Roussillon speakers if other ways of asking questions seemed natural to them in Catalan: és que SVO or que VOS. Among the speakers, five said they were familiar with the form és que SVO, 4 with the form in que VOS, 3 with both forms and 2 with neither one nor the other. They were then recorded in the corresponding form(s).

\section{Overall observations and methodological choices}

In this study, only controlled sentences of the form SVO were analyzed, in interrogative and assertive modalities. They are a total of over 4,000 sentences.

These questions and statements were segmented into vowel nuclei, following the AMPER modelling. Fundamental frequency $\left(F_{0}\right)$ measurements were accordingly

JoSS 4 (2) $59-72$ 
taken, using the PRAAT software (Boersma, 2001), at the beginning, midpoint and end of each vowel. The segmentation was performed by forced alignment using the LIMSI automatic speech recognition system (Gauvain et al. 2005) and checked by experts. After manual corrections, the results were plotted as exemplified in Figure 3 for the $F_{0}$ representation of a question in French and Occitan.
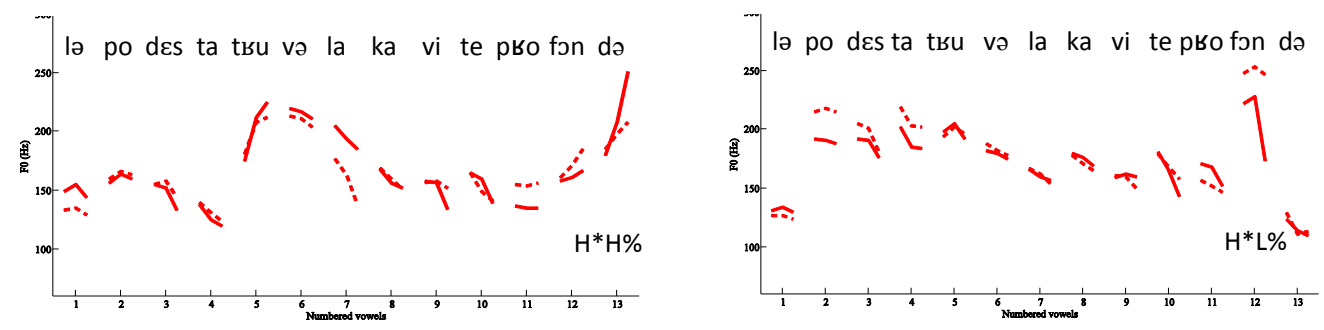

Fig. 3: vowel-based representation of $F_{0}$ (regardless of duration) for the sentence "does the Podestà find the deep cavity?" pronounced by a

Languedocian speaker (on the left, with a $\mathrm{H}^{*} \mathrm{H} \%$ pattern) and a

Provençal speaker (on the right, with a $\mathrm{H}^{*} \mathrm{~L} \%$ pattern), in French (solid line) and in Occitan (dotted line).

\subsection{Prosodic analyses}

As in previous studies (Sichel-Bazin et al, 2012, 2015; Boula de Mareuil et al., 2013, 2015), assertive intonation (with a falling finality contour) shows strong similarities between regional French and regional languages. In oxytone-final questions, there is a near- categorical pitch rise on the last (stressed) syllable of the utterance, regardless of the language variety. In the other questions, the intonation differences mentioned above were observed.

In questions ending in an atone vowel, Provence and Languedoc speakers showed high within-subject consistency: 9 of them (7 Languedocians, 2 Provençals) regularly opted for the $\mathrm{H}^{*} \mathrm{H} \%$ pattern, 5 of them (3 Provençals, 2 Languedocians) for the $\mathrm{H}^{*} \mathrm{~L} \%$ pattern in Occitan as in French. In this configuration, 3 Roussillon speakers relatively regularly opted for the $\mathrm{L}^{*} \mathrm{H} \%$ pattern, 3 for the $\mathrm{H}^{*} \mathrm{H} \%$ pattern, the other 8 exhibiting variable behaviors in Catalan and French (a $\mathrm{L}^{*} \mathrm{H} \%$ pattern in Catalan and a $\mathrm{H}^{*} \mathrm{H} \%$ pattern in French, especially, in 5 speakers). In Catalan, on the other hand, 2 speakers (the older ones, who reported speaking Roussillonese rather than Catalan) tended to stress proparoxytone words on the penultimate syllable, but without this being systematic; the other speakers naturally stressed words like búlgara 'Bulgarian' and pública 'public' on the antepenultimate syllable.

No particular $F_{0}$ threshold was used. Computing $F_{0}$ differences between the midpoint of the utterance-final vowel and the midpoint of the previous two vowels, percentages of pitch patterns were quantified. Results are summarized in Table 2.

\begin{tabular}{|c|c|c|c|c|}
\hline Language variety & Catalan & $\begin{array}{c}\text { French in contact } \\
\text { with Catalan }\end{array}$ & Occitan & $\begin{array}{c}\text { French in contact } \\
\text { with Occitan }\end{array}$ \\
\hline \%rises on the stressed vowel & 48 & 71 & 95 & 96 \\
\hline \%rises on the last vowel & 96 & 90 & 58 & 63 \\
\hline
\end{tabular}

Table 2: percent $F_{0}$ rises from the midpoint of the pre-stressed vowel to the 
midpoint of the stressed vowel ( $2^{\text {nd }}$ row $)$ and from the midpoint of the stressed vowel to the midpoint of the final vowel (bottom row) in questions ending in paroxytone word, in the different language varieties.

In this table, it is noticeable that the only figure below $50 \%$ is the percentage of rises on the stressed vowel in Catalan. Indeed, the $\mathrm{L}^{*} \mathrm{H} \%$ pattern is the majority in Catalan paroxytone-final questions. In the other three language varieties, the $\mathrm{H}^{*} \mathrm{H} \%$ pattern is the majority.

\subsection{Selected sentences}

For perception tests, two sentences were selected (the ones reported in Table 1), ending in paroxytones - caserne 'barracks' and profonde 'deep', where the final schwa is (almost) always pronounced in southern French or their counterparts in Occitan/Catalan. These sentences, in their interrogative modality in French, were used in two perceptual experiements, to check whether different intonational contours may be associated with this or that region, especially. In both experiments, the final contours were manipulated by prosody modification/resynthesis.

\section{Experiment 1: Provence/Languedoc}

\subsection{Method and protocol}

The listening test was designed to check whether or not differences in perception could be highlighted between Provençal and Languedocian speakers of French. It was a pair- wise test in which listeners were asked, between two versions of the same question, which one sounded closer in its intonation to what they were used to hearing in their region. For this experiment, the two questions mentioned above were selected (see Table 1), in southern French, in order to get 10 $\mathrm{H}^{*} \mathrm{H} \%$ patterns and $10 \mathrm{H}^{*} \mathrm{~L} \%$ patterns. As many reversed patterns were generated by resynthesis, using PRAAT, so as to make each rising- falling pattern $\mathrm{H}^{*} \mathrm{H} \%$ and each rising-rising pattern $\mathrm{H}^{*} \mathrm{~L} \%$. In addition, $\mathrm{L} * \mathrm{H} \%$ patterns, which were absent from the Occitan speakers' data, were created. The average values in semitones (ST) of these different patterns are illustrated in Figure 4.

Speakers were matched according to their mean pitch, so as to have different intonation contours $\left(\mathrm{H}^{*} \mathrm{H} \%\right.$ or $\left.\mathrm{H} \% \mathrm{~L} \%\right)$. In the resulting question pairs, participants were asked to compare different intonation contours from different speakers. This precaution was intended to avoid attracting listeners' attention to the very subject of our study. Subjects, for example, listened to the two French questions illustrated in Figure 3, separated by a 1-second interval. A total of 40 question pairs (equalized in intensity) were presented to listeners: 10 originals of the type $\mathrm{H}^{*} \mathrm{H} \%-\mathrm{H}^{*} \mathrm{~L} \%, 10$ synthesized stimuli of the type $\mathrm{H}^{*} \mathrm{H} \%-\mathrm{H}^{*} \mathrm{~L} \%, 10$ synthesized stimuli of the type $\mathrm{L} * \mathrm{H} \%-\mathrm{H} * \mathrm{~L} \%$ and 10 synthesized stimuli of the type $\mathrm{L} * \mathrm{H} \%-\mathrm{H} * \mathrm{H} \%$. 
BOULA DE MAREüIL. Philippe et al.

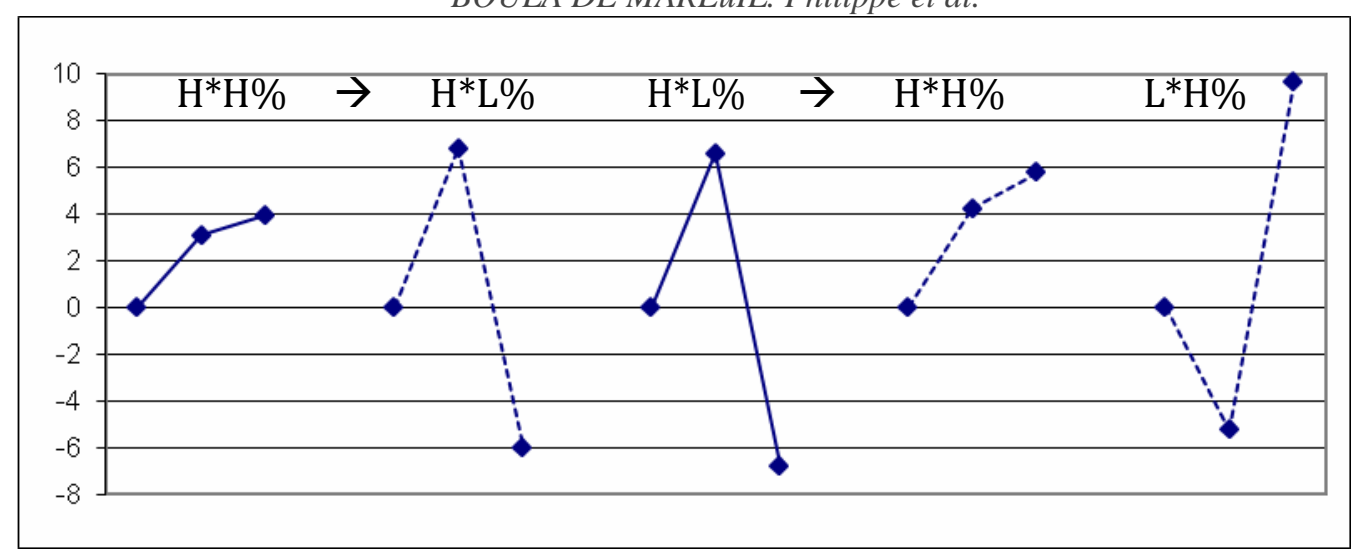

Fig. 4: mean slopes (in semitones) of $F_{0}$ differences taken at the midpoint of the 3 question-final vowels for the original intonation patterns (solid lines) and patterns modified by synthesis (dashed).

The test, conducted through a web interface, lasted about 20 minutes. Participants were informed that the experiment concerned French spoken in the South (specifically questions recorded in Provence and Languedoc) and that they would have to listen to speech which could possibly be modified acoustically. They were encouraged to use headphones or earphones. Subjects first had to provide biographical information (age, place of residence, etc.). A familiarization phase followed, with the type of stimuli: the original and changes in prosody not used in the test itself, to illustrate different intonation patterns of different regions under study. In the actual test, stimuli were presented in a pair-wise manner, in a different random order for each subject. Subjects could listen to each pair as many times as they wanted, but it was impossible to correct answers, once a new pair was displayed. For each question pair, subjects were asked to indicate which version sounded closer, in its intonation, to what they were used to, by clicking on one of the two available buttons. At the end of the test, they were asked to optionally specify the cues on which they had relied in making their decisions.

\subsection{Listeners}

In total, 40 subjects participated in the test (17 males and 23 females, aged 37 on average). They were 20 Provençal and 20 Languedocian speakers, with no reported history of speech or hearing disorders. They were fairly well established in their region, since they had lived 33 years on average in the Midi (the South). All were native speakers of French, with only one subject defining himself as a French-Occitan bilingual.

Prior to the test, subjects were questioned about their familiarity with the southern French accent and Occitan. They were asked if they thought they could distinguish Provençal and Languedocian speakers of French: 16 listeners out of 40 responded in the positive. Additionally, they were asked if they happened to have (or to hear, respectively) conversations in Occitan - once a week or a few times a month, rarely or never: 36 (27, respectively) listeners responded that it never happened to them, or only seldom.

\subsection{Results}

The results of Experiment 1 are shown in Figure 5, in the different 
configurations where two intonational patterns were matched. They were subjected to $\chi^{2}$ tests which showed a significant preference only in acoustically modified stimuli, for the $\mathrm{H}^{*} \mathrm{H} \%$ pattern (matched with $\mathrm{H}^{*} \mathrm{~L} \%\left[\chi^{2}(1)=26 ; p<0.001\right]$ and $\mathrm{L}^{*} \mathrm{H} \%\left[\chi^{2}(1)=34\right.$; $p<0.001])$.

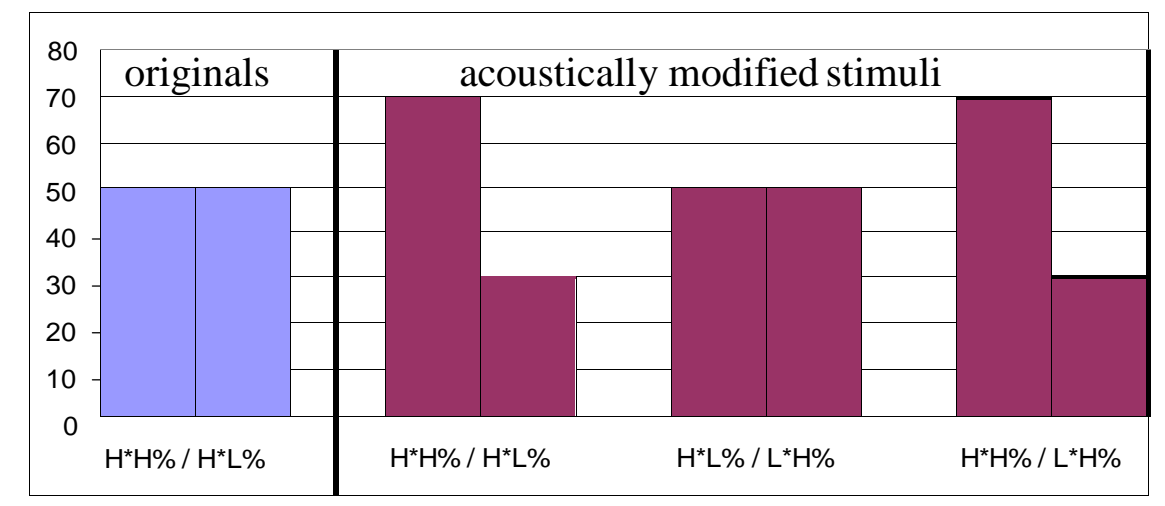

Fig. 5: results of Experiment 1: percentage of cases in which listeners declared themselves more familiar with the $\mathrm{H}^{*} \mathrm{H} \%, \mathrm{H}^{*} \mathrm{~L} \%$ or $\mathrm{L}^{*} \mathrm{H} \%$

patterns, in different question pairs where these patterns were competing (original stimuli on the left, resynthesized stimuli on the right).

Between the $\mathrm{H}^{*} \mathrm{H} \%$ and $\mathrm{H}^{*} \mathrm{~L} \%$ originals, responses are balanced: the differences are not significant, as between $\mathrm{H}^{*} \mathrm{~L} \%$ and $\mathrm{L} * \mathrm{H} \%$. The differences between Provence and Languedoc listeners' responses are not significant either. These results suggest that in the two regions under investigation, some variation is allowed as far as question intonation is concerned. Even if the $\mathrm{H}^{*} \mathrm{H} \%$ pattern is the most accepted, the others are not completely rejected, including the $\mathrm{L} * \mathrm{H} \%$ pattern, which was synthetically created (since it was absent from the originals).

The analysis of the results by speaker did not show clear trends: sometimes a speaker from Languedoc is overall perceived as more familiar by listeners from Provence, sometimes a speaker from Provence is overall perceived as more familiar by listeners was observed.from Languedoc. In any case, no bias linked to a common origin of speakers and listeners

At the end of the test, subjects' comments mentioned the "accent" and/or "intonation" of speakers (about 20 times), possibly qualified as "sing-song" (5 times). However, they are not precisely attributed to a particular region, and in those impressionistic terms, they are difficult to analyze.

\subsection{Discussion}

According to the study, the $\mathrm{H}^{*} \mathrm{H} \%$ pattern is the most characteristic of questions in French in contact with Occitan. Also, the $\mathrm{H}^{*} \mathrm{~L} \%$ pattern can be observed. As for the $\mathrm{L}^{*} \mathrm{H} \%$ pattern, it was judged less familiar to listeners than the $\mathrm{H}^{*} \mathrm{H} \%$ rise, but it competes with $\mathrm{H}^{*} \mathrm{~L} \%$, when matched with the latter pattern. These findings raise the 
BOULA DE MAREüIL. Philippe et al.

issue of interpretation and function of these different intonational patterns.

\section{Experiment 2: Provence/Languedoc/Roussillon + functionality}

\subsection{Material and protocol}

A second perceptual experiment was conducted, including Roussillon speakers and listeners, asking questions on functionality. For this experiment, 3 speakers from Provence ( 1 male and 2 females exhibiting $\mathrm{H}^{*} \mathrm{~L} \%$ patterns), 3 speakers from Languedoc ( 2 males and 1 female exhibited $\mathrm{H}^{*} \mathrm{H} \%$ patterns) and 3 speakers from Roussillon ( 1 male and 2 females exhibiting $\mathrm{L} * \mathrm{H} \%$ patterns) were selected.. As previously, the two French sentences presented in Table 1 were kept and subjected to prosody modification/resynthesis so as to explore the three contours $\mathrm{H}^{*} \mathrm{H} \%, \mathrm{H}^{*} \mathrm{~L} \%$ and $\mathrm{L}^{*} \mathrm{H} \%$. The $\mathrm{L}^{*} \mathrm{H} \%$ originals, on average, exhibited a $-1 \mathrm{ST}$ pitch fall followed by a $+9 \mathrm{ST}$ rise in the end of questions. As for the $\mathrm{H}^{*} \mathrm{~L} \%$ and $\mathrm{H}^{*} \mathrm{H} \%$ stimuli generated by resynthesis, they had the average slopes shown in Figure 4 for the corresponding originals.

The resulting 54 stimuli (whose intensity was equalized) were presented in random order to the subjects of a new test, the task of which was twofold: identify the origin of the speech sample (3 possibilities: Provence, Languedoc, Roussillon) and the speech act performed (3 possibilities: confirmation query, incredulous question, request for information). More precisely, listeners were asked whether, on the basis of intonation, the speaker who asked the question was more likely to expect a yes-type answer (confirmation query), a no-type answer (disbelief) or a yes/no answer (I don't know).

\subsection{Listeners}

At the time of writing these lines, 30 southern listeners took part in the test $(9$ males and

21 females, aged 36 on average): 9 from Provence, 14 from Languedoc, 7 from Roussillon. They had spent 30 years in the Midi, on average. Yet, a minority of subjects

(13) also felt able to distinguish Provençal, Languedocian and Roussillonese speakers of French. 25 subjects (19, respectively) reported they never or only seldom had (heard, respectively) conversations in Occitan or Catalan.

\subsection{Results}

The results of Experiment 2 are shown in Table 3. For the first task (i.e. identifying speakers' region of origin), listeners achieved a $32 \%$ correct identification score (36\% for Provence, $29 \%$ for Languedoc, $32 \%$ for Roussillon), which is not significantly different from random according to a $\chi^{2}$ test. There was no significant effect of the type of pitch pattern according to a $\chi^{2}$ test: percentages of correct identification are $34 \%$ for $\mathrm{H}^{*} \mathrm{H} \%$ stimuli, $34 \%$ for $\mathrm{H}^{*} \mathrm{~L} \%$ stimuli and $32 \%$ for $\mathrm{L}^{*} \mathrm{H} \%$ stimuli. Nor do results support Sichel-Bazin et al.'s (2012, 2015) assumptions, illustrated in Figure 2. Yet, participants' responses significantly differ across the pitch pattern types. For example, listeners judged that the $\mathrm{H}^{*} \mathrm{H} \%$ pattern required a yes-type answer in $46 \%$ of cases and a no-type answer in $24 \%$ of cases, whereas the H*L\% required a yes-type answer in $38 \%$ of cases and a no- type answer in $41 \%$ of cases. The speech acts perceived by listeners differ significantly between $\mathrm{H}^{*} \mathrm{H} \%$ and $\mathrm{H}^{*} \mathrm{~L} \%$ patterns $\left[\chi^{2}(2)=37.3 ; p<0.001\right]$. Based on these figures, the $\mathrm{H}^{*} \mathrm{H} \%$ pattern is rather a confirmation query and the $\mathrm{H}^{*} \mathrm{~L} \%$ pattern rather an incredulous question. However, a 
more in-depth analysis with more listeners is necessary before concluding.

\begin{tabular}{|c|c|c|c|c|c|c|}
\cline { 2 - 7 } \multicolumn{1}{c|}{} & \multicolumn{3}{c|}{ Correctly identified region } & \multicolumn{3}{c|}{ Identified speech act } \\
\hline $\begin{array}{c}\text { Respons } \\
\text { e Pattern }\end{array}$ & Provence & Languedoc & Roussillon & $\begin{array}{c}\text { Confirmatio } \\
\text { n query }\end{array}$ & $\begin{array}{c}\text { Incredulous } \\
\text { question }\end{array}$ & $\begin{array}{c}\text { Request for } \\
\text { information }\end{array}$ \\
\hline $\mathrm{H}^{*} \mathrm{H} \%$ & 34 & 30 & 29 & 46 & 24 & 30 \\
\hline $\mathrm{H}^{*} \mathrm{~L} \%$ & 39 & 30 & 32 & 38 & 41 & 21 \\
\hline $\mathrm{L} * \mathrm{H} \%$ & 39 & 27 & 34 & 41 & 32 & 27 \\
\hline
\end{tabular}

Table 3: results of Experiment $2(\%)$ for the various pitch patterns $\left(\mathrm{H}^{*} \mathrm{H} \%, \mathrm{H}^{*} \mathrm{~L} \%\right.$ and $\left.\mathrm{L} * \mathrm{H} \%\right)$, in terms of identified regions and speech acts.

As in Experiment 1, final comments, possibly mentioning a sing-song intonation, are difficult to analyze.

\subsection{Discussion}

From Experiment 2, it turns out that the region of origin of French speakers from Provence, Languedoc and Roussillon is identified close to random, on the basis of short sentences. Instead, questions exhibiting various pitch patterns may be interpreted differently. The prediction was that the $\mathrm{H}^{*} \mathrm{~L} \%$ pattern, ending in a final low tone as a statement, might be interpreted as a confirmation query. Rather, it was perceived as an incredulous question in our experimental setup. Surprisingly, too, the default response was not a request for information but seemed to be a confirmation query - in the case of the $\mathrm{H}^{*} \mathrm{H} \%$ pattern, especially, which was the most frequent contour in our data. This may be due to the way in which the corpus was collected (eliciting questions immediately followed by positive answers) or the fact that, in real life, we probably ask more questions calling for yes-type answers than questions calling for no-type answers. For the $\mathrm{L}^{*} \mathrm{H} \%$ pattern, further research is definitely needed.

\section{Conclusion}

This article presented a field survey conducted in Provence, Languedoc and Roussillon, including rather transparent sentences in Occitan, Catalan and French, the prosodic structures of which were compared. Yes/no questions, in particular, were analyzed: rising-rising patterns $\left(\mathrm{H}^{*} \mathrm{H} \%\right)$, rising-falling patterns $\left(\mathrm{H}^{*} \mathrm{~L} \%\right)$ and falling-rising patterns $\left(\mathrm{L}^{*} \mathrm{H} \%\right)$, at the end of questions, were observed, in Occitan, Catalan and southern French

- unlike what is prototypically noticed in standard (northern) French, where due to the drop of the final schwa, the utterance-final syllable is the one which bears nuclear stress.

Two perceptual experiments centered on question intonation were conducted, based on recordings of French, using modification/re-synthesis. Although some variation is tolerated, the first test suggests that listeners from Languedoc and Provence (with no significant differences between the two groups) are more familiar with the $\mathrm{H}^{*} \mathrm{H} \%$ pattern. This result, in perception, is in keeping with the observation that this pattern prevails in our data in French in contact with Occitan as in 
Occitan. Rather atypical in Romance languages for paroxytones, this melodic pattern of questioning (which was also found in Roussillon French, in most cases, whereas the majority pattern in Catalan is $\mathrm{L}^{*} \mathrm{H} \%$ ) needs to be studied in more detail with respect to its functionality.

A second perceptual test, which was expanded to recordings collected in Roussilon, has not enabled us to determine the role of request for information associated with the $\mathrm{H}^{*} \mathrm{H} \%$ rise, as hypothesized by Sichel-Bazin et al. (2012, 2015). Instead, this pattern was associated with a confirmation query in French in contact with both Occitan and Catalan. This study should be continued, with more listeners and spontaneous speech. Undoubtedly, in spontaneous speech, the functional interpretation of the utterances will represent another challenge (Fontaney, 1991).

\section{Acknowledgements}

This work was supported by the ANR project PADE. We are indebted to P. Mairano, J.-P. Lai, I. Lehka-Lemarchand, M. Barkat-Defradas, H. Tyne, all the speakers we recorded and all the listeners who volunteered to participate in the perceptual experiments.

\section{References:}


BLANCHET, P. (2004). L'identification sociolinguistique des langues et des variétés linguistiques : pour une analyse complexe du processus de catégorisation fonctionnelle. Workshop MIDL, Paris, 31-36.

BoERSMA, P. (2001). Praat, a system for doing phonetics by computer. Glot International, 5(9/10): 341-345.

Boula de MareüIL, P., Rilliard,A., Mairano, P., LAI, J.-P. (2012). Corsican French questions: is there a prosodic transfer from Corsican to French and how to highlight it? $6^{\text {th }}$ International Conference on Speech Prosody, Shanghai, 418-421.

Boula de MareüIL, P., Rilliard, A., LehKA-Lemarchand, I., IVEnT, F. (2013). Regional accents and languages in France: a contrastive prosodic analysis of Romance varieties. ISCA Workshop on Phonetics, Phonology and Languages in Contact (PPLC), Paris, 72-75.

Boula de Mareüil, P., Rilliard, A., LehKa-Lemarchand, I., Mairano, P., Lai, J.-P. (2015). Falling yes/no questions in Corsican French and Corsican: evidence for a prosodic transfer. In Delais-Roussarie, É., Avanzi, A., Herment, S. (Eds.), Prosody and languages in contact. L2 acquisition, attrition, languages in multilingual situations, Springer Verlag, Berlin, 101-122.

BOYER, H. (2004). Langue et nation : le modèle catalan de nationalisme linguistique. Mots, 74, 26-41.

Contini, M., Lai, J.-P., Romano, A., Roullet, S., De Castro Moutinho, L., COIMBRA,

R. L., Pereira Bendiha, U., Secca Ruivo, S. M. (2002). Un projet d'Atlas Multimédia Prosodique de l'Espace Roman. $1^{\text {st }}$ International Conference on Speech Prosody, Aixen- Provence, 227-230.

COQUILlon, A. (2005). Caractérisation prosodique du parler de la région marseillaise, Phd thesis, Université de Provence.

Delattre, P. (1966). Les dix intonations de base du français. The French Review, 401: $1-14$.

Di CRISTO, A. (1998). Intonation in French. In Hirst, D. J. \& Di Cristo, A. (Eds.), Intonation systems: A survey of twenty languages, Cambridge University Press, Cambridge, 195-218.

FisHMAN, J. A. (1991), Reversing language shift: Theoretical and empirical foundations of assistance to threatened languages, Multilingual Matters, Clevedon. FÓNAGY, I. (2003). Des fonctions de l'intonation: Essai de synthèse. Flambeau, 29: 1- 20. FONTANEY, L. (1991). À la lumière de la question. In Kerbrat-Orecchioni, C. (Ed.), La question, Presses Universitaires de Lyon, Lyon.

Gauvain, J.-L., Adda, G., AdDA-Decker, M., Allauzen, A., Gendner, V., LAMEl, L., SCHWENK, H. (2005). Where are we in transcribing French broadcast news? $9^{\text {th }}$ European Conference on Speech Communication and Technology, Lisbon, 1665-1668.

Grundstrom, A. \& LÉOn, P. (1973). Interrogation et intonation, Didier, Montreal. Héran, F., Fillon, A., DePrez, C. (2002). La dynamique des langues en France au fil $\mathrm{du}$ $\mathrm{XX}^{\mathrm{e}}$ siècle. Population et Sociétés, 376: 1-4.

HuALDE, J. I. (2003). Remarks on the diachronic reconstruction of intonational patterns in Romance with special attention to Occitan as a bridge language. Catalan Journal ofLinguistics, 2: 181-205. 
Martinet, A. (1970). Éléments de linguistique générale, Armand Colin, Paris.

Martínez Celdrán, E., Fernández Planas, A. M., Carrera Sabaté, J., Espuny MonserRAT, J. (2005). Approche de la carte prosodique dialectale de la langue catalane en Catalogne. Géolinguistique - Hors série 3: 103-151.

MeISENBURG, T. (2011). Prosodic phrasing in the spontaneous speech of an Occitan French bilingual. In Gabriel, C. \& Lleó, C. (Ed.), Intonational phrasing in Romance and Germanic, Cross-linguistic and bilingual studies, John Benjamins, Amsterdam, 127-151.

PIERREHUMBERT, J. (1981). Synthesizing intonation. Journal of the Acoustical Society ofAmerica, 70: 985-995.

PRIETO, P. (2001). L'entonació dialectal del català: el cas de les frases interrogatives absolutes. In Bover, A., Lloret, M. R., Vidal-Tibbits, M. (Ed.), Actes del Novè Col-loqui de la North American Catalan Society, Publicacions de l'Abadia de Montserrat, Barcelona, 347-377.

SAVINO, M. (2012). The intonation of polar questions in Italian: Where is the rise? Journal of the International Phonetic Association, 42(1): 23-48.

Sichel-BAzIN, R. \& Roseano, P. (2013). Català septentrional. In Prieto, P. \& Cabré, T. (Eds.), L'entonació dels dialectes catalans, Publicacions de l'Abadia de Montserrat, Barcelona,102-123.

Sichel-Bazin, R., ButhKe, C., Meisenburg, T. (2012). La prosodie du français parlé à Lacaune : influences du substrat occitan. In Simon, C. (Ed.), La variation prosodique régionale en français, De Boeck, Brussels, 137-157.

Sichel-BAZIN, R., Meisenburg, T., Prieto. P. (2015). Intonational phonology of Occitan: Towards a prosodic transcription system. In Frota, S., \& Prieto, P. (Eds.), Intonational variation in Romance. Oxford University Press, Oxford, 198-234.

Tuaillon, G. (1996). Le domaine gallo-roman. In Tuaillon, G. \& Contini, M. (Eds.), Atlas Linguistique Roman (AliR), Volume I présentation, Istituto poligrafico e zecca dello stato, Roma, 53-84.

Vanrell, M. M., Mascaró, I, Torres-Tamarit, F., Prieto, P. (2013). Intonation as an

encoder of speaker certainty: information and confirmation yes-no questions in Catalan. Language and Speech, 56(3): 163-190.

Woehrling, C. \& Boula DE MAReÜIL, P. (2006). Identification d'accents régionaux en français : perception et analyse. Revue Parole, 37: 25-65. 